\title{
Miljöfrågornas stora genombrott i Sverige, hösten 1967
}

Hösten 1967 förändrades den svenska miljödebatten. En rad framstående forskare gick då ut i offentligheten och varnade för en hotande global katastrof. Genomslaget var kraftfullt. Det talades om ett allmänt uppvaknande. I press, radio och tv rapporterades det om kvicksilverförgiftad fisk, biocider och surt regn. Lars J. Lundgren har träffande uttryckt det som att en ny problemkontinent upptäcktes. Tidigare hade olika miljöfaror betraktats som enskilda problemöar. Nu började allt fler se dem som sammanlänkade med varandra. ${ }^{52}$

I centrum för utvecklingen stod Hans Palmstierna. Han publicerade i oktober månad en debattbok i pocketformat: Plundring, svält, förgiftning. Med denna ville han "väcka och skapa klarhet" kring människans situation. Han framhöll att det var en tvingande nödvändighet att handla "innan timglaset runnit ut för mänskligheten" ${ }^{53}$ Kännetecknande för Palmstierna var att han sammanförde miljöförstöring med andra globala frågor, som världsfattigdom, krig och överbefolkning. Han framhöll att jorden var ett litet klot med begränsad yta. Därför måste vi "hejda befolkningsökningen om människan skall överleva". ${ }^{4}$ Framför sig såg han en apokalyptisk tid som människan måste gå igenom "för att botas till förnuft och ödmjukhet inför de obevekliga lagar som råder i allt levande". ${ }^{55}$

Palmstiernas tonläge var högt och skarpt, men inte unikt. I förordet till en annan debattbok i pocketformat utgiven hösten 1967, Människans villkor: En bok av vetenskapsmän för politiker, skrev Karl-Erik Fichtelius, professor i histologi vid Uppsala universitet: "Domedagsprofeter 
har det funnits så länge det funnits människor. Det nya har inträffat att nu kan varje politiskt medveten vetenskapsman ställa upp som domedagsprofet." ${ }^{56}$

Fichtelius var redaktör för, och initiativtagare till, Människans villkor. Boken samlade tolv tunga forskarnamn, däribland fysikern Hannes Alfvén, nationalekonomen Gunnar Myrdal och livsmedelsforskaren Georg Borgström. Boken gavs ut i december och vållade en intensiv debatt kring relationen mellan vetenskap och politik. Men redan i oktober månad höll en av de medverkande, ledamoten i Svenska Akademien Lars Gyllensten, ett uppmärksammat radioföredrag. Där lyfte han fram att de biologiska grundvillkoren för människans tillvaro var på väg att omintetgöras. Kunskapen om det allvarliga tillståndet var utbredd, menade han, men den togs inte på allvar. Det krävdes en "medveten, effektiv och osentimental omskolning av oss alla" för att de globala problemen skulle kunna lösas. ${ }^{57}$

Mänsklighetens överlevnad var själva kärnan i den svenska miljödebatten hösten 1967. Men miljöfrågorna diskuterades också på ett mer lågmält sätt. En central position hade socialdemokraten Valfrid Paulsson. Han hade i juli samma år tillträtt som generaldirektör för Statens naturvårdsverk. De flesta naturvetenskapliga forskare följde också den mer dämpade linjen. Detta märktes inte minst i 1964 års naturresursutrednings betänkande, vilket överlämnades i november 1967. Bakom de två volymerna stod landets vetenskapliga expertis på miljöområdet. Utredningen hade kartlagt kunskapsläget kring, och omfattningen av, olika former av förgiftning och nedsmutsning. Perspektivet var nationellt snarare än globalt. Bättre planering och mer forskningsresurser efterfrågades. Det var inte tal om att människorna måste omskolas eller att en världsregering borde upprättas. ${ }^{58}$

I betänkandet pekades dock på att miljöproblemen inte var någon strikt nationell angelägenhet. Särskilt gällde detta Svante Odéns upptäckt av surt regn. Utsläppen skedde på kontinenten, men regnet föll ned över Sverige. Internationellt samarbete var nödvändigt för att komma till rätta med problemet. Anmärkningsvärt är hur insikten om faran offentliggjordes. Det skedde genom en artikel på Dagens Nyheters kultursida skriven av Svante Odén själv. Den ingick i artikelserien "Miljö 
för framtiden” vilken löpte från september till december. Ledande naturvetenskapsmän bereddes där plats att ingående presentera och diskutera olika miljöproblem. Odéns artikel kom omedelbart att föra upp försurningen på den dagspolitiska agendan. ${ }^{59}$

Till den nationella sidan av miljödebatten hörde också kvicksilverförgiftningen. Under sommaren 1967 hade det uppdagats att fisken i många svenska insjöar uppmätte höga halter av kvicksilver. Det infördes förbud mot att sälja fisken. För många yrkesfiskare innebar det arbetslöshet. Händelserna rönte stor medial uppmärksamhet. De visade att miljögifter var ett direkt hot mot människors liv och uppehälle.

Den händelserika hösten 1967 rymde som synes många teman, riktningar och röster. På grund av detta kom Hans Palmstierna att få en speciell funktion. Han talade om mänsklighetens överlevnad och om globala frågor, men var också starkt engagerad i nationella och lokala problem - ibland av rent teknisk art. Dessutom rörde han sig på olika arenor. Han var en verksam vetenskapsman och aktiv socialdemokrat som skrev regelbundet i Dagens Nyheter. Denna kombination av vetenskapligt, politiskt och medialt kapital gav honom en unik plattform att verka från. ${ }^{60}$

Miljöfrågornas genombrott i Sverige var intimt sammanflätat med Hans Palmstiernas gärning. Hösten 1967 vann han erkännande som vetenskaplig expert på miljö- och framtidsfrågor. Paul Warde och Sverker Sörlin har betecknat detta som en speciell form av vetenskaplig metaexpertis. De menar att efterkrigstidens miljöbegrepp och vetenskaplig framtidsexpertis samproducerades. Miljöbegreppet hade, menar de, redan från början en temporal riktning som pekade framåt mot en hotande katastrof. Kunskap om framtiden och vetenskaplig expertis på miljöområdet utvecklades gemensamt, som två sidor av samma mynt. ${ }^{61}$ Men hur skedde då detta i Sverige hösten 1967?

\section{Väckarklockan Hans Palmstierna}

Fredagen den 27 oktober sändes ett längre inslag med Hans Palmstierna på tv-nyheterna. Vid denna tid fanns det bara en tv-kanal i Sverige. Kvällsnyheterna var populära. I inslaget visades Plundring, svält, förgift- 
ning upp. På omslaget fanns en bild av kunskapens träd på gott och ont. Boken var helt nyutkommen och Palmstierna var fortfarande okänd för de allra flesta. För reportern berättade han om den "jättekomplexa förgiftningen vi utsätts för". Mot bakgrund av bilder på rykande skorstenar, slammande avloppsrör och trafikstockningar talade han om bly, kvicksilver och fosfater. Han framhöll vidare att svälten var ett permanent världstillstånd. Inom ett decennium skulle den träffa oss. De stigande köttpriserna var ett förebud om en värld där maten inte räckte till. ${ }^{62}$

Samma dag uppmärksammades Plundring, svält, förgiftning av landets då största kvällstidning Expressen. Där framhölls det att boken var en av de mest pessimistiska hittills. Skribenten frågade sig: "Hur långt har vi egentligen kvar på jorden? Tio år? Femton?” Det lyftes fram att det viktigaste som hände just nu var "att vi äntligen försöker mäta katastrofens hela omfattning" och "börjar närma oss sanningen" ${ }^{63}$ Några dagar senare karaktäriserade morgontidningen Skånska Dagbladet boken som "den hårdaste, mest komprimerade vidräkningen med den moderna civilisationens slöseri med naturens tillgångar man kan tänka sig”. ${ }^{64}$ Boken satte omedelbart avtryck. Det dröjde dock ett par veckor innan den på allvar hamnade i pressens fokus.

Den 11 november tog Dagens Nyheter på ledarplats ett samlat grepp om Plundring, svält, förgiftning och Naturresursutredningens betänkande. Hans Palmstiernas bok beskrevs som en "faktaspäckad och fascinerande thriller om jordens tillstånd och människornas behov". Tillsammans med betänkandet rekommenderades den varmt. De båda skrifterna kunde väcka till insikt och mana till handling. Men ledarskribenten menade också att "uppvaknandet inför miljöproblemen" redan var långt på väg. Det fanns kunskap hos politiker, näringsliv och i opinionerna om vad som hände och vad som behövde göras. "Viljan till handling saknas inte heller", inskärpte skribenten. Därigenom kombinerades allvarliga krisinsikter med tillförsikt. ${ }^{65}$

Dagen därpå skrev Aftonbladets ledarsida om Palmstiernas bok. Där framhölls det att författaren inte sparade på krutet när han visade upp "vilken ohållbar utveckling vi råkat in i". På ett begränsat utrymme tog han ett helhetsgrepp på "det gigantiska problemkomplex, på vars lösning framtiden hänger”. Det som gjorde insatsen särskilt förtjänstfull 
var att Palmstierna inte enbart fokuserade på problemen. Aftonbladet framhöll att han hela tiden sökte efter konstruktiva lösningar. Det knöts i boken ett visst hopp till socialism, vetenskapligt sanningssökande och internationell solidaritet. "Man har all anledning att önska", avslutade ledarskribenten, "att hans bok inte bara når svenska läsare - utan även når ut över gränserna".66

Andra pressröster tog fasta på de apokalyptiska inslagen. I Kvällsposten frågade sig Staffan Ulfstrand om vi hade nått början på slutet. Den hotande katastrofen skulle "drabba hela jordklotet". Det fanns inga nya kontinenter att fly till. Några "mån- och planetfärder" skulle inte lösa befolkningsproblemen. Plundring, svält, förgiftning lyftes fram som initierad, väldokumenterad och uppskakande läsning. Den borde sättas i händerna på alla. ${ }^{67}$ Det höga tonläget föranledde emellertid också en viss oro. Många tänkte säkert att "Palmstierna målar fan på väggen helt i onödan". ${ }^{68}$ Och var det inte så att "naturvetenskaparnas talande fakta" började bli "som vilken skvalmusik som helst", undrade den kooperativa rörelsens veckomagasin $V i{ }^{69}$

De flesta pressröster tog dock fasta på att Hans Palmstiernas bok var en angelägen väckarklocka. Den enda kritiska rösten var Nils Landell som skrev för Svenska Dagbladet. Han ansåg att boken genomsyrades av ett alltför stort patos och ett för tunt faktaunderlag. Det borde ha varit fler exempel och färre "irrelevanta funderingar", ansåg han. Särskilt vände sig Landell mot Palmstiernas politiska ställningstaganden. Han ställde sig skeptisk till att just en socialistisk regering skulle vara bäst lämpad för att ta itu med de allvarliga problemen. Tvärtom borde alla stater, oavsett samhällssystem, verka för att lösa de globala problemen. ${ }^{70}$ Landells kritik var dock av marginell betydelse och föranledde inte heller någon diskussion. Den dominerande åsikten i pressen var att Plundring, svält, förgiftning var intressant, tillgänglig och vetenskapligt oklanderlig. Det var en viktig bok som man hoppades skulle läsas av många. 


\section{Från kunskap till handling}

Den 21 november skrev Hans Palmstierna om Naturresursutredningens betänkande i artikelserien "Miljö för framtiden". Han inledde med att lyfta fram att kvicksilverutsläppen från massaindustrin hade gjort en hel fiskarkår arbetslös. Biociderna hotade det högre djurlivet. Fosfaterna i tvättmedlen gjorde att sjöar grodde igen och svavelregnet utgjorde en stor fara. Allt detta var problem som kommit till allmänhetens kännedom. "Än väntar många överraskningar", skrev han. Gissningsvis skulle framtida utredningar "ge lika otäcka avslöjanden".

Men hur hade vi försatt oss i denna situation? Varför fördärvade vi vår omgivning så att vår livssituation hotades? Palmstierna hade svaret klart för sig:"Vi har önskat en snabbt stigande levnadsstandard." För att möjliggöra denna hade produktionen styrts mot att tillverka saker så billigt som möjligt. Utan hänsyn till de långsiktiga konsekvenserna. Lika förödande var det att "vi helst glömmer bort de varor vi konsumerat". Genom att betala minsta möjliga för avfallshanteringen hade levnadsstandarden kunnat höjas mycket snabbt. Men naturens räkning hade ännu inte presenterats. "Blir den så hög att vi inte kan betala den?" frågade han sig.

Palmstierna framhöll att det var för att få överblick över situationen som 1964 års naturresursutredning hade tillsatts. Dess betänkande gav "en utomordentligt klar och lättläst genomgång" av problemens art och allvar. Det kunde läsas av alla med intresse för frågorna. Palmstierna lyfte fram att utredningen presenterade nya och skrämmande fakta, däribland Svante Odéns rön om surt regn. Dessutom gav betänkandet inblick i "den ringa kunskap vi ännu besitter". För att råda bot på detta krävdes målinriktad forskning och större forskningsresurser. Därtill behövde de statliga kontrollerna av industrier och kommuner intensifieras.

Hans Palmstierna underströk att politikerna behövde fullödig information från experter för att kunna fatta genomtänkta beslut. Naturresursutredningen hade nu gett detta. Vad han dock saknade var ett preliminärt handlingsprogram. Ett sådant kunde komplettera informationen och göra den mer användbar för politiker. Kostnaderna fick inte avskräcka. 
Den individuella levnadsstandarden kunde inte tillåtas "fortsätta stiga på vår framtida hälsas och våra barns bekostnad".

Artikeln avslutades med att Palmstierna lyfte fram en amerikansk utredning. Den blottlade än mer skrämmande fakta än den svenska. På miljöförstörelsens område var det, menade han, lyckligtvis så att Sverige låg tio år efter USA. Den amerikanska utredningen hade dock ett par konkreta förslag som han uppskattade. Det första gick ut på att i möjligaste mån återföra konsumerat material till produktionen. Genom att utveckla rationella "cirkelförlopp" kunde man undvika de största skadeverkningarna. Det andra förslaget var att upprätta en experimentstad. I denna kunde på statens bekostnad ny teknik utprovas. Lyckade innovationer och system kunde därefter spridas över landet. Därtill kunde experimentstaden användas för att utbilda miljövårdsexperter, en yrkesgrupp som Palmstierna såg ett stort behov av att formera. ${ }^{71}$

Palmstiernas artikel visade upp hans breda register. Det rådde ingen tvekan om hur allvarligt han uppfattade situationen, men det framgick också att han såg ett betydande handlingsutrymme. Palmstierna var konkret och framåtblickande. Därtill uppvisade han en stor tilltro till politik, teknik och vetenskap. Detta förhållande har lyfts fram av Jonas Anshelm, som menar att Palmstiernas synsätt därmed inte utmanade socialdemokratins traditionella utvecklingsoptimism. Förhållandet var avgörande, menar Anshelm, för att Palmstierna skulle få en politisk nyckelroll när Socialdemokraternas miljöpolitik formerades. ${ }^{72}$ En sådan roll hade han dock inte hösten 1967. Hans Palmstierna hade ännu inte erbjudits några politiska uppdrag. Men hans expertis på miljö- och framtidsfrågor var på väg att befästas. Avgörande var att han kom att uppfattas som handlingskraftig.

I början på december publicerade Dagens Nyheter en stort uppslagen och mycket uppskattande recension av Plundring, svält, förgiftning. Den talande rubriken var "Från kunskap till handling". Recensionen var skriven av författaren och ingenjören Sven Fagerberg. Han var en tongivande röst i 1960-talets svenska samhällsdebatt och hade under lång tid diskuterat globala ödesfrågor. I recensionen tog han avstamp i den utvecklingsoptimism som han menade hade rått i samhällets ledande skikt under den tidiga efterkrigstiden, i synnerhet på det tek- 
niska området: "De påtagliga framstegen som gjordes på många håll tycktes bekräfta att man var på rätt väg." Men med tiden började bilden mörkna. Det kom att resas frågetecken kring världshushållningen och utvecklingens riktning. "Vårt välstånd vilar på falsk grund", slog han fast, "på en nedbrytningsprocess av engångsnatur." Detta innebar att vi stal "från kommande generationer, våra egna och inte minst u-ländernas." Det var en "besk sanning" som partier och intresseorganisationer hade svårt att ta till sig. Deras ledare hade nämligen formats av den tidiga efterkrigstidens utvecklingsoptimism. Den nya problembilden stämde inte överens med denna. Ledarna klamrade sig därför fast vid en förlegad världsbild. De gjorde det dock inte av illvilja, ansåg Fagerberg, utan av oskuld och oförmåga.

Den ödesdigra situationen stod dock fullt klar. "Problemet är", skrev han, "att levandegöra den kunskap som finns." Det var detta som han ansåg att Palmstierna gjorde så förtjänstfullt. Boken var "mycket väl belagd med fakta" men var samtidigt medryckande och handlingsinriktad. Palmstiernas största förtjänst var att han hörde "till det fåtal vetenskapsmän som känner sitt ansvar och inser att de måste gripa in i det praktiska skeendet". Dessutom pekade han "hela tiden på möjligheter till praktiska åtgärder". I detta fanns det, som Fagerberg uttryckte det, "ett mått av satsning, av vitalitet". Detta var helt nödvändigt. Den som ville förändra världen var tvungen att ta risker: "Väntar vi tills varje kråkvinkel av ett problemkomplex blivit belyst, är vi för sent ute."

Sven Fagerbergs recension framställde Hans Palmstierna som en modig, brett orienterad och ansvarskännande vetenskapsman. Han hoppades att Plundring, svält, förgiftning kunde göra miljövården till en politisk stridsfråga. Kanske kunde Sverige rentav bli ett föregångsland? I avslutningen framhöll han att landet hade en god ekonomi, hög teknisk kompetens och skickliga forskare. Därtill ödslades inga resurser på militära ambitioner eller rymdritualer. "Vi är praktiskt lagda och tänker bäst på materiella ting", skrev han. "Vi är just inte intresserade av någonting alls, och sålunda lediga för engagemang." ${ }^{73}$ Miljövårdens och Hans Palmstiernas tid var nu.

Sven Fagerbergs recension är ett av de tydligaste exemplen på hur kunskap om en hotande miljökris och Hans Palmstiernas framtids- 
orienterade expertis samproducerades hösten 1967. Men Fagerberg var långtifrån ensam i sin bedömning. Tvärtom rådde det i början på december stor enighet i den svenska offentligheten om att Palmstierna var en kunnig, pragmatisk och handlingsinriktad miljödebattör. I Göteborgs Handels- och Sjöfartstidning skrev Bengt Hubendick, en av de mest profilerade ekologiska rösterna i Sverige vid denna tid, att Plundring, svält, förgiftning borde delas ut till "alla i politiskt och tekniskt ansvarig ställning" med "krav på genomläsning och begrundan" ${ }^{74} \mathrm{I}$ Göteborgsposten framhöll Göran Michanek att Palmstierna hade lyckats med någonting nytt. Han hade visat att miljöförstörelse inte var något avlägset katastrofhot. Det gällde oss själva och våra barn. ${ }^{75}$ Det var hög tid att gå från kunskap till handling.

\section{Vetenskap, politik och expertisens gränser}

Den breda uppslutningen kring Hans Palmstierna och Plundring, svält, förgiftning kom under december månad att kontrasteras mot den intensiva debatt som uppstod kring forskarantologin Människans villkor. De två debattböckerna var till synes snarlika, men kom att uppfattas på mycket olika sätt. Hur detta gick till och vad det fick för konsekvenser ska jag nu titta närmare på.

Torsdagen den 7 december, dagen innan Människans villkor nådde bokhandeln, uppmärksammades den i det tv-sända veckomagasinet "Monitor". Sändningen inleddes med att tre ord rullade förbi på skärmen: världsbrand, världssvält, världsförgiftning. Därefter visades bilder på svältande och utmärglade barn från tredje världen. De starka bilderna ackompanjerades ironiskt av en sjungen version av "Gud som haver barnen kär", den mest populära aftonbönen för barn i 1960-talets Sverige.

Programmets obehagliga öppningsscen följdes av att Georg Borgström, filmad i sitt kontor och omgiven av böcker, talade om globala orättvisor, undernäring och överbefolkning. Han inskärpte att vi befann oss i "initialskedet av en monumentalkris" och att vi alla måste ta av oss våra skygglappar. "En olustig påminnelse mitt i den begynnande julbrådskan, inte sant?" sade speakerrösten. Därefter visades bilder av skorstenar, bilavgaser och förorenade vattendrag. "Olust väcker också 
bilder som dom här", fortsatte rösten, "vi vräker ut gifter och gaser och farliga ämnen i naturen och över oss själva med följder som vi vet alldeles för lite om. Bara att dom kan bli förödande."

"Monitor" fortsatte med att flera av forskarna bakom boken kom till tals. Ekologen Bengt Lundholm, som hade varit sekreterare i 1964 års naturresursutredning, talade om DDT och kvicksilver. Fysikern Tor Ragnar Gerholm riktade uppmärksamheten mot världens kärnvapenarsenaler. Carl-Göran Hedén, professor i bakteriologi vid Karolinska Institutet, ställde sig kritisk till det rådande politiska systemet. Han ansåg att den nationella organiseringen och de korta mandatperioderna var en bräcklig grund att stå på i ett läge där människoartens överlevnad stod på spel.

Programmet avslutades med en studiodebatt mellan Lars Gyllensten och det socialdemokratiska statsrådet Krister Wickman. I detta inslag kastades ordningen om. Det var inte vetenskapsmannen Gyllensten som ställde politikern Wickman till svars, utan tvärtom. Statsrådet fick första ordet. Han vände sig mot den bild av politiker som fanns i boken. Forskarna tycktes anse att politiker "cyniskt utnyttjar en lättledd okunnig väljarmassa". Detta synsätt vittnade om ett djupt politikerförakt, men än allvarligare om ett väljarförakt. Ville Gyllensten ersätta den politiska demokratin med teknokratiskt expertstyre?

Debattörernas kroppsspråk var betecknande. Wickman satt offensivt framåtlutad. Gyllensten tittade ner i golvet. Han försäkrade att han inte vände sig mot demokratin eller närde ett förakt för politiker och väljare. Vad han önskade var endast att det vetenskapliga inflytandet skulle bli större. Wickman förde samtalet vidare genom att leda in det på långoch kortsiktiga målsättningar. De diskuterade vilken roll politiker hade för att skapa opinioner. Här rådde det en betydande enighet. Båda två såg det som politikerns uppgift att leda och forma opinioner, inte endast verkställa det för dagen möjliga. Wickman avslutade med att lyfta fram att hela problematiken i hög grad var en "kunskaps- och insiktsfråga". Han medgav att samhället under lång tid hade underskattat riskerna på miljöområdet. Men just nu "upplever vi ju en sån påtaglig förändring $\mathrm{i}$ inställningen till dom här frågorna”. Förutsättningarna för att nå fram till en lösning var goda. Därmed fick "Monitor" ett milt optimistiskt och lugnande avslut. ${ }^{76}$ 
Den efterföljande dagen uppmärksammades både tv-programmet och boksläppet i pressen. ${ }^{77}$ Dessutom publicerade Svenska Dagbladet en första recension. Där karaktäriserades vetenskapsmännens initiativ som i sak lovvärt, men i praktiken föga konstruktivt. I boken fanns nämligen inga förslag på "konkreta politiska åtgärder" utan endast "välmenande och vaga recept". Recensenten frågade sig om inte "en och annan konkret anvisning" hade kunnat anges för politikerna, i stället för att "bara i största allmänhet skälla ut dem och förklara dem otidsenliga?" Med ett sådant grepp hade samarbetsvilja kanske kunnat byggas upp. ${ }^{78}$

Några dagar senare fortsatte Aftonbladets ledarsida på samma linje. Det välkomnades att vetenskapsmän grep in i samhällsdebatten. Men det förakt för politiker - och ytterst för väljare - som kom till uttryck i boken vände man sig kraftigt emot. Särskilt var det Carl-Göran Hedén och Lars Gyllensten som fick utstå kritik. De tycktes se vetenskapsmän som upplysta sanningssökare och politiker som maktlystna vilseledare. Ledarskribenten framhöll att den här typen av förakt var en "ofruktbar utgångspunkt" för att få till stånd ett fördjupat samarbete. Dessutom underströks det att forskarna "glatt medverkat till att skapa de tekniska framsteg som nu är dödliga hot mot mänskligheten". Därför var det en "ovanligt omotiverad högfärdighet" att framställa vetenskapsmän, i motsats till politiker, som "moraliska renlevnadsmän". ${ }^{79}$

Kritiken var skarp även på Dagens Nyheters ledarsida. Redan bokens undertitel väckte frågor. Varför vände sig vetenskapsmännen bara till politiker? Angick inte de stora framtidsfrågorna alla människor? Ledarskribenten underströk att samhällen varken kunde, eller borde, styras av "hierarkiska elitkopplingar av forskare-politiker-tekniker". Dessutom framhölls att mycket var på väg att hända i världen. Såväl i Sverige som utomlands började miljöfarorna allt mer att tas på allvar. Politiker och forskare var viktiga för utvecklingen, "men inte centralare än andra påverkare och maktfaktorer i samhället". ${ }^{80}$

Av de tolv vetenskapsmännen bakom Människans villkor var det endast Carl-Göran Hedén som försökte bemöta kritiken. Han framhöll att han såg politiker som en stor tillgång, men att partipolitiken utgjorde en allvarlig fara. Den borde, i möjligaste mån, ersättas av den "vetenskapliga metodiken". För Hedén rörde det sig alltså inte om huru- 
vida vetenskapsmän eller politiker var mest moraliska. Det handlade om skilda arbetssätt, där han föredrog vetenskapens och menade att detta borde få större inflytande på samhällsstyrningen. Hedén talade sig varm för en "dynamisk realdemokrati", med vilket han avsåg frekventa folkomröstningar om specifika frågor. ${ }^{81}$

Carl-Göran Hedéns inspel göt dock ingen olja på vågorna. Under hela december månad fortsatte Människans villkor att kritiseras i pressen. Genomgående betonades det att vetenskapsmännen lyfte fram angelägna frågor, men att de också uppvisade elitistiska och antidemokratiska tendenser. ${ }^{82}$ Särskilt kritisk var den folkpartistiske politikern Carl Tham (sedermera socialdemokrat). Han menade att forskarnas angrepp på politikerna hade ett "betänkligt släktskap" med den kritik mot "demokratins principer som tidigare hävdats av den yttersta högern". ${ }^{3}$ Anmärkningsvärt i sammanhanget är att bokens redaktör, Karl-Erik Fichtelius, inte deltog i debatten. Detta är förvånande eftersom Fichtelius var en van debattör. Anledningen står att finna i att han vid tiden befann sig i USA på en längre gästforskarvisit. ${ }^{84}$

Den utbredda och samstämmiga kritiken av Människans villkor visar på att det fanns skarpa gränser för vetenskaplig expertis i 1960-talets Sverige. Forskarna fick gärna definiera problem, sprida kunskap och skapa opinioner. Men när de på ett konfrontativt sätt rörde sig in på det politiska beslutfattandets område stötte de på ett kraftfullt motstånd. Samtidigt bidrog uppmärksamheten kring Människans villkor otvetydigt till att kunskap om en global miljökris cirkulerade i offentligheten. Både i boken och i pressdebatten blev det tydligt att många människor hade börjat betrakta miljöförstörelse som ett sammanhängande problemkomplex, intimt sammanlänkat med andra överlevnadsfrågor. Vetenskaplig framtidsexpertis cirkulerade dock på ett ambivalent sätt. Vissa forskare, som Lars Gyllensten och Carl-Göran Hedén, betraktades med skepsis och misstänksamhet. Hans Palmstierna kom i stället att ytterligare stärka sin position. 


\section{Konsolideringen av Hans Palmstiernas expertis}

I den livliga debatten kring Människans villkor hänvisades det ofta till Plundring, svält, förgiftning. Men den växande kritiken mot vetenskapsmännen riktades aldrig mot Palmstierna. Tvärtom. Hans bok fortsatte att hyllas. Den 13 december lyfte Sydsvenska Dagbladet fram den som ett av de "fränaste, mest uppslagsrika, bäst informerade och därtill bäst framförda" debattinlägg som gjorts i Sverige på mycket länge. Det framhölls att Palmstierna hade en bred bildning, inte bara inom naturvetenskap utan också inom humaniora. Han förmådde gå utanför sitt eget snäva kompetensområde och vågade uttala sig om de verkligt stora frågorna. "Och det är väl detta som är nödvändigt", skrev recensenten, "att det finns en elit av orädda debattörer med tillräckligt vid referensram för att kunna tänka tvärvetenskapligt". ${ }^{85}$

Accentueringen av Palmstiernas stora bredd och vittomfamnande kunskaper var utmärkande för hur hans expertis cirkulerade. Centralt var även att han karaktäriserades som en optimist. En skribent uttryckte det som att man hade kunnat förutsätta att "Palmstierna med allt sitt vetande" för länge sedan skulle ha slutat tro på det meningsfulla i att vädja till "det enskilda eller kollektiva förnuftet". Men så var inte fallet. Palmstierna var, trots att han insåg situationens allvar, en optimist som trodde på människorna. Gemensamma ansträngningar kunde "avvärja de hotande olyckorna". ${ }^{86}$

På julafton 1967 skrev Gösta Bringmark en krönika i Arbetet utifrån den bibliska berättelsen om förvisningen ur Edens lustgård. Han framhöll att den moderna människan nu hade fått lära sig att "kunskapen verkligen är något på gott och ont". Det underströks att "vår teknologi håller på att ta död på vår egen existens" och att "människan är en sjuklig organism i naturen eller en jordens parasit". Det var förbluffande, menade Bringmark, med vilken hastighet dessa synsätt hade etablerats. Miljövårdsfrågorna hade "äntligen börjat bryta igenom på bred front". Han oroade sig dock för att en spricka var på väg att bildas mellan vetenskapsmän och politiker. "Det är av ytterlig vikt, att den klyftan inte blir djupare", manade han. Den person som borgade för att så kunde bli fallet var Hans Palmstierna. Bringmark ansåg att han 
bättre än någon annan hade förmått ta ett "koncist och uppfordrande grepp" på de stora ödesfrågorna. ${ }^{87}$

Kontrasterna i hur den svenska pressen hanterade de olika vetenskapsmännens inspel var påfallande. Kunskapen som åberopades var i hög grad den samma. Men det sätt som forskarnas expertis cirkulerade på skiljde sig åt. Palmstierna framställdes som resonabel och politiskt konkret, medan forskarna bakom Människans villkor betraktades som högmodiga och vaga. Detta bidrog till att ytterligare stärka Palmstiernas position. I en växande kör av vetenskapliga varningsröster stod han senhösten 1967 ut som förnuftig och pragmatisk.

Därtill hade Palmstierna tillgång till en helt central medial plattform: Dagens Nyheters kultursida. Tidningen hade på 1960-talet en ledande position i den svenska samhällsdebatten och var drivande i att föra upp miljöfrågorna på agendan. Inte minst genom Barbro Sollers journalistik. Hon hade blivit anställd som allmänreporter på tidningen 1964 och gradvis utvecklats till att bli miljöreporter. Barbro Soller blev Sveriges, och en av världens, första heltidsanställda miljöjournalister. ${ }^{88}$ Dessutom gjorde Dagens Nyheter flera satsningar på att få in vetenskapsmän som skribenter i tidningen. Artikelserien "Miljö för framtiden" stod här centralt och det fanns bara en vetenskapsman som gavs möjlighet att skriva två artiklar där: Hans Palmstierna.

Den 29 december publicerades "Insikt, kunskap, handling”. Det var den nionde och avslutande delen i artikelserien. Palmstierna inledde med att slå fast att "insikten att jorden är liten och att mänskligheten har makt att förstöra sina möjligheter att leva vidare dagades sent". Han lyfte fram att den började ta form när atombomberna föll över Hiroshima och Nagasaki, men att det aldrig uppstod någon "massrörelse". I stället vande sig människor "vid att leva under hotet av förintelse". I skuggan av bomben växte dock nya insikter fram. Forskare upptäckte gradvis att många industriella processer var högst riskabla för den "natur vi lever i och lever av". Miljön var känsligare än vi hade trott.

Palmstierna inskärpte att vi nu "hårdhänt fått uppleva att jorden är liten och livet bräckligt". Dessa insikter var inte längre "ett litet fåtals egendom", skrev han, "utan tillhör numera allmänheten". Det hade dock tagit lång tid att nå denna avgörande punkt. Vetenskapsmännen, 
som under lång tid intuitivt känt riskerna, hade inte haft "tillräckligt med belägg för att kunna övertyga”. Palmstierna hävdade att samhället hade "fordrat en alltför detaljerad kunskap innan det ville sätta tilltro till varningarna". Många hade reagerat negativt på insikterna och slagit dem ifrån sig.

Anledningen var, enligt Palmstierna, att kommunikationerna mellan vetenskapsmän och politiker inte fungerat. "Det förekommer ännu ingen lugn och förtroendefull dialog", skrev han. Därför måste "en ny grupp tolkar urskiljas ur vetenskapsmännens led". Personer som kunde "översätta vetenskapens rön och varningar till klar och tydlig normalprosa, så att även myndigheter och allmänhet kan få en oförfalskad bild av skeendet”. Det var denna roll som han själv tog på sig. Det var det första nödvändiga steget mot en livsduglig miljö. Målet var att skapa beredvillighet hos politiker och allmänhet för att acceptera de ingripande och kostsamma åtgärder som situationen krävde. Upplysningsarbetet fick inte heller stanna vid nationella gränser. Problemen var gränsöverskridande. Det behövde vetenskapsmännens opinionsbyggande också vara.

Avslutningsvis betonade Palmstierna än en gång att den individuella levnadsstandarden inte kunde tillåtas stiga mer på den gemensamma miljöns bekostnad. Fortgick detta skulle vi snart inte längre ha "någon livsduglig omgivning att leva i - och leva av". Han underströk att utvecklingsoptimism inte hade något berättigande i den allvarliga situationen, men det hade inte pessimism heller. "Det gäller att klart se fakta i ögonen", skrev han, "och handla rationellt på grundval av den kunskap vi har". Endast så kunde vi garantera att vår generation, och kommande, "överlever på ett människovärdigt sätt". ${ }^{9}$

Med sin artikel kom Palmstierna att sätta punkt för den svenska miljödebatten 1967. Denna hade, till följd av hans och andra vetenskapsmäns agerande, på kort tid förändrats i grunden. Kunskap om en global miljökris, liksom vetenskaplig framtidsexpertis, cirkulerade nu intensivt i den svenska offentligheten. Men ett samhälleligt kunskapsgenombrott går inte att studera på ett fullödigt sätt genom att endast studera offentligheten. Det som händer där är viktigt, men det finns också andra arenor som är avgörande för hur kunskap rör sig och ver- 
kar i ett samhälle. I det följande ska jag därför belysa miljöfrågornas genombrott utifrån två möten i maktens korridorer.

\section{Forskningsberedningens möte om miljövårdsfrågor}

Måndagen den 4 december 1967 sammanträdde Forskningsberedningen under ledning av dess ordförande statsminister Tage Erlander för att diskutera miljövårdsforskning. Forskningsberedningen var, namnet till trots, inget beredande organ utan fungerade snarare som en mötesplats för politiker, vetenskapsmän och andra nyckelpersoner i stat och näringsliv. Den hade inrättats 1962 för att fördjupa samarbetet dem emellan. Utgångspunkten var att forskning ansågs spela en nyckelroll för samhällsutvecklingen. Forskningsberedningen var ett steg i riktning mot en mer aktiv statlig forskningspolitik. Dess betydelse markerades av att den svenska statsministern själv ledde arbetet. ${ }^{90}$

Mötet den 4 december samlade 47 personer, däribland en stor mängd statsråd, professorer och direktörer för olika myndigheter. Utöver de ordinarie deltagarna i Forskningsberedningen hade 14 personer kallats särskilt för att närvara vid just detta tillfälle, däribland Hans Palmstierna och Svante Odén. Det råder ingen tvekan om att Forskningsberedningen samlade en samhällselit. Hur cirkulerade kunskap och expertis i ett sådant sammanhang?

Mötet inleddes med att statsminister Erlander höll ett längre anförande. Där konstaterade han att det numera var uppenbart att "vår miljö är allvarligt hotad”. Varningssignalerna kom allt tätare, både i Sverige och utomlands. Sjöar växte igen, surt regn föll från himlen och fisken fördärvades. Den pågående förgiftningen försämrade villkoren för jord- och skogsbruk. Växt- och djurliv hotades. "Är vi på väg”, frågade sig statsministern, "att stegvis och delvis omärkligt omöjliggöra vår existens genom miljöförstöringen?"

Erlander fortsatte sitt anförande med en historisk tillbakablick. Han framhöll att "i ett läge där de materiella bristerna är skarpt markerade kommer miljön i andra hand". Så hade det varit tidigare och politikens mål hade därför satts till "att skapa ökad produktion, att skapa arbete, att snabbt höja levnadsstandarden”. Därför hade miljön i Sverige, liksom 
i andra industriländer, exploaterats för att säkerställa "grundläggande materiella behov". Erlander underströk att man "inte ett ögonblick" fick underskatta vad denna tekniska och ekonomiska utveckling hade betytt för människorna. Den hade möjliggjort "höjd konsumtion, större social trygghet, mer fritid och en rad andra ting". Denna utveckling skulle även i fortsättningen värnas, men man måste "på ett helt annat sätt än tidigare ta hänsyn till miljön", fastslog han.

Erlander argumenterade för att miljöfrågorna i ökad utsträckning borde uppfattas som "en del av den sociala verklighet som den enskilde upplever". När levnadsstandarden ökade, steg också kraven på miljön. Genom att "hejda naturförstöringen, nedsmutsningen och förgiftningen" säkrades tryggheten. För att klara av detta krävdes samarbete mellan stat, kommuner och näringsliv. Det var orimligt, ansåg Erlander, att begära av enskilda företag att de skulle kunna överblicka de långsiktiga miljömässiga konsekvenserna av den egna verksamheten. Miljöproblemen var en fråga för samhället som helhet. Det var på en politisk nivå som regler och gränser behövde fastställas. Detta ställde krav på "gemenskap i värderingarna" och ett solidariskt handlande.

Mot slutet av anförandet slog statsministern an en existentiell ton och blickade framåt. Han erkände att det var "lätt att känna maktlöshet inför miljöproblemens storlek", men han inskärpte att vi inte behövde känna så. "Vi har större ekonomiska resurser än någonsin", påpekade han, "forskarna har gjort en banbrytande insats för att göra oss medvetna om miljöproblemens aktualitet." Självklart krävdes mer kunskap och överblick, men "det är ytterst på vår vilja det kommer an". Erlander slog fast att regeringen var beredd att gå vidare. Han framhöll att "avståndet mellan kunskap och åtgärd måste bli så kort som möjligt". Ny forskning och ny teknik skulle utvecklas. "Vad dagens diskussion gäller", avslutade han, "är hur vi med forskningens hjälp skall kunna trygga en livskraftig miljö åt människorna, en miljö som vi skall kunna överlämna till efterkommande generationer." ${ }^{\text {91 }}$

Erlanders anförande visar att miljöfrågorna vid denna tid hade slagit rot hos individer på Sveriges högsta politiska nivå. Statsministern var fullt på det klara med miljöfrågornas allvar. Betoningen av att en snabbt stigande levnadsstandard hade fått oförutsedda konsekvenser påminde 
om hur Palmstierna och andra debattörer karaktäriserade utvecklingen. En viktig skillnad var dock att Erlander var mycket noga med att också framhålla utvecklingens positiva sidor. Människor hade fått det bättre. De materiella framstegen var reella och önskvärda. Klockan skulle inte vridas tillbaka. Erlanders förhoppning var att forskning och politik kunde hantera de oönskade sidoeffekterna och säkerställa en fortsatt positiv samhällsutveckling.

Diskussionen som följde tog sitt avstamp i Naturresursutredningens betänkande. Särskilt diskuterades organisatoriska frågor. Utredningen hade föreslagit att det skulle inrättas en miljövårdsberedning direkt underställd jordbruksministern. Denna skulle få till uppgift att finansiera såväl grundforskning som målinriktad forskning. Många av de närvarande professorerna yttrade sitt bifall. De menade att forskningen behövde mer resurser för att kunna åstadkomma samhällsförändring. För närvarande hämmades man av att det rådde brist på forskare och att de projekttjänster som kunde erbjudas inte var tillräckligt attraktiva. Menade regeringen allvar med sin satsning måste basanslagen höjas. Det gick varken att locka eller behålla de bästa forskarna med ett- och tvååriga kontrakt. ${ }^{92}$

Den organisatoriska relationen mellan det nyinrättade Naturvårdsverket och den föreslagna Miljövårdsberedningen diskuterades livligt. De aktiva forskarna argumenterade för värdet av självständighet medan andra röster menade att en samordning kunde göra steget kortare från forskning till handling. Flygöverdirektör Lars Brising menade att "allt vore att vinna" på att göra Naturvårdsverket till "en kompetent och därmed handlingskraftig exekutiv institution". ${ }^{93}$ Värdet av att samordna framfördes också av Martin Fehrm, generaldirektör på Försvarets forskningsanstalt (FOA). Han underströk vikten av att "utnyttja forskningens resultat i samhällets planering" och menade att det var angeläget att befintlig kunskap snarast sattes in i "en modell- eller totalbild". Denna typ av systemanalys var, enligt Fehrm, "ett av de viktigaste elementen i en målbunden miljövårdsforskning". Han underströk också att Naturresursutredningens kostnadsberäkningar var i underkant. Menade regeringen allvar med att "gå till attack mot naturresursproblematiken" så skulle man vara beredd på "väsentligt högre kostnader". ${ }^{4}$ 
De ekonomiska aspekterna lyftes också av Erik Dahmén, professor i nationalekonomi vid Handelshögskolan i Stockholm. Han framhöll att det fanns "mycket starka samhällsekonomiska skäl" för att sätta in åtgärder mot miljöförstörelsen och fördjupa miljövårdsforskningen. Dahmén ansåg att "uppoffring av miljövärden" behövde uppfattas som kostnader - precis som "råvaror, kapital och arbetskraft". För närvarande fanns ingen prismekanism, vilket medförde att "kortsiktiga konsumtionspreferenser" gynnades på miljövärdenas bekostnad..$^{95}$ Dessa tankar skulle Dahmén året därpå vidareutveckla i den uppmärksammade debattboken Sätt pris på miljön: Samhällsekonomiska argument i miljöpolitiken (1968). ${ }^{96}$

Bankdirektör Tore Browaldh följde upp Dahméns tankegångar. Han lyfte fram möjligheten att "på sikt lösa miljöproblemen genom att utnyttja marknadsprisbildningen". Detta kunde exempelvis ske genom att specialbeskatta miljöskadliga produkter. Browaldh framhöll dock att en specifikt svensk beskattning riskerade att slå hårt mot svenska företag som verkade på en hårt konkurrensutsatt internationell marknad. Likväl föreslog han att Dahmén borde ges i uppdrag att leda en arbetsgrupp som kunde utarbeta ett förslag kring hur marknadsprisbildning kunde utformas och introduceras på miljöområdet. Browaldh tänkte sig vidare att en kraftfull forskningsinsats på miljöområdet på sikt kunde resultera i uppbyggandet av en ny svensk industrigren inom miljöteknik.

En annan aspekt som återkommande lyftes var behovet av internationellt samarbete. Här fanns stor enighet, men också viss oro. Sune Bergström, professor i medicinsk och fysiologisk kemi vid Lunds universitet, framhöll att det inom OECD fanns en stor brist på kunskap och intresse. Det var "endast ett fåtal medlemsländer" som var "medvetna om problemets allvar". Därför kunde Sverige inte passivt invänta framtida internationella överenskommelser. I stället borde vi sträva efter att bli "ett föregångsland och genom denna primärinsats öka intresset för problematiken i andra länder" ${ }^{97}$ Även Nobelpristagaren Arne Tiselius, professor i biokemi vid Uppsala universitet, ansåg att regeringen skulle vara proaktiv. Han föreslog att Sverige skulle verka för inrättandet av ett internationellt forskningsråd. Detta kunde sedan ha strategiskt ansvar för att få till stånd "brådskande målinriktad forskning". 98 
Mot slutet av mötet yttrade sig Hans Palmstierna. Han tryckte på "behovet av upplysning till allmänheten". Därtill menade han att biologer " $i$ väsentligt högre utsträckning" borde användas för att informera tekniker. Palmstierna instämde också i Dahméns påpekande att "alltför stora konsumtionsfördelar" hade tagits ut med "förstörd natur som resultat". Han inskärpte dock att fördelningen var ojämn. Den som förstörde naturen, och profiterade på detta, var sällan den som drabbades. Här fanns en orättvisa som inte fick glömmas bort. ${ }^{99}$

Forskningsberedningens möte hade som synes betydande likheter med den offentliga miljödebatten. Kunskap och expertis cirkulerade på snarlika, om än inte identiska, sätt. Skillnaden bestod framför allt i att man på Forskningsberedningens möte - med undantag för Tage Erlanders inledningsanförande - inte talade om miljöfrågorna i termer av mänsklighetens överlevnad. Slående är också att överbefolkning och globala orättvisor inte diskuterades. På Forskningsberedningens möte definierades miljöproblematiken snävare. Det talades inte om ett kristillstånd eller en framtida global katastrof. Samtalet präglades i första hand av Naturresursutredningens betänkande och det mer lågmälda sätt som miljöfrågorna diskuterades på där. Den apokalyptiska inramningen, som var viktig i den offentliga debatten, var inte betydelsefull här.

\section{Ett möte på Försvarets forskningsanstalt (FOA)}

Den 27 november, en vecka innan Forskningsberedningens sammanträde, hölls ett möte på FOA. Även detta handlade om hur forskning kunde bidra till en positiv samhällsutveckling. I fokus stod emellertid inte naturvetenskaplig och teknisk expertis, utan samhällsvetenskaplig och humanistisk. Anledningen till detta var att generaldirektören Martin Fehrm ansåg att miljöproblemen ytterst handlade om mänskliga handlingar och politiska beslut. Därför var naturvetenskapliga och tekniska kunskaper inte tillräckliga. För att ge politikerna ett fullgott beslutsunderlag krävdes också andra kompetenser. ${ }^{100}$

I maj månad 1967 hade Martin Fehrm sammankallat till ett första möte på FOA. Bland de inbjudna fanns tre professorer: nationalekonomen Assar Lindbeck, statsvetaren Pär-Erik Back och historikern Birgitta 
Odén. Vid detta första möte gjorde dessa klart för Martin Fehrm att den kunskap som han efterfrågade inte fanns. Forskare hade inte tidigare intresserat sig för miljöfrågornas historiska, politiska och ekonomiska dimensioner. För att få fram sådan kunskap krävdes nya forskningsinsatser. Här föddes en idé till ett gemensamt forskningsprogram.

En annan fråga som restes var hur man skulle få politiker och allmänhet att inse situationens allvar. Fehrm själv betraktade miljöförstörelsen som ett säkerhetshot, jämförbart med andra yttre hot mot samhällets fortbestånd. Denna förståelse ställde de övriga sig bakom. I diskussionerna föddes en idé om att författa en gemensam debattbok. Birgitta Odén fick i uppdrag att dra upp riktlinjerna för en sådan. Den 27 november presenterade hon ett diskussionsunderlag.

Den form som hon tänkte sig var "en mindre skrift, skriven så lättfattligt som möjligt. Alltså: en seriös pamflett, avsedd att väcka diskussion”. För att få effekt behövde den komma ut så snabbt som möjligt, helst redan våren 1968. Tanken var att experter skulle komma till tals och väcka politiker och allmänhet till insikt om "frågans allvar och nödvändigheten av en snabb målinriktad forskning". Hennes PM, totalt fem sidor, innehöll ett detaljerat synopsis där tilltänkta författare angavs. Odén lade särskild vikt vid förordet. Detta borde skrivas av "en person med gehör hos opinionen". Temat skulle vara "välståndsutvecklingens och teknikens oförutsedda följdverkningar och deras för våra barns framtid ödesdigra konsekvenser”. Den person hon ville tillfråga för uppgiften var den socialdemokratiska politikern och diplomaten Alva Myrdal, som på internationell nivå arbetade med nedrustningsfrågor. ${ }^{101}$

Förordet skulle följas av en inledning med gruppens gemensamma programförklaring. Där skulle framhållas att miljöförstöringen var "ett så allvarligt hot mot vårt framtida välstånd, att det kan likställas med en militär säkerhetsrisk". Det var detta som motiverade att FOA tog på sig ledarrollen för verksamheten. Målsättning för forskningen skulle vara att "skaffa bättre information till ledning för dem som fattar de avgörande besluten”. Den tilltänkta författaren var Martin Fehrm under medverkan av hela gruppen. ${ }^{102}$

De tre följande kapitlen skulle behandla historiska exempel på ödesdiger miljöförstörelse, politiska beslutsprocesser på miljöområdet samt 
frågan om hur vetenskaplig informationsspridning gick till inom politiska organ. För dessa delar av skriften kunde Birgitta Odén själv och Pär-Erik Back ha ett särskilt ansvar. Därefter följde sex kapitel av naturvetenskaplig, medicinsk och säkerhetspolitisk karaktär. Däribland ett kapitel om nederbördens försurning av Svante Odén, ett om folkhälsoproblematiken av Hans Palmstierna samt ett om Östersjön och Sveriges säkerhetspolitik av överingenjör Erik Moberg på FOA. Avsikten med det sistnämnda kapitlet var att visa att "Östersjöns nedsmutsning kan leda till att Sovjet ställer krav på oss, som vi kan ha svårt att uppfylla". Frågan var dock om detta kunde sägas öppet eller om det blott skulle underförstås. ${ }^{103}$ Kallakrigskontexten - i vilken Sverige sökte hålla en neutral linje - var här starkt närvarande. ${ }^{104}$

Dessa kapitel med konkreta problembeskrivningar skulle följas av ett avsnitt där miljöförstöringen skärskådades ur en nationalekonomisk synvinkel. I detta kunde man visa att kostnadskalkylerna för i princip all industriell produktion blev för låga "om man inte även inräknar utgiften för återställelse av natur i kalkylen". Kapitlet skulle utmynna i en plädering för "realistisk kostnadsberäkning" och en diskussion av "var kostnaderna för miljöåterställelse skall tagas ut". I det trettonde och avslutande kapitlet skisserades ett samlat grepp på miljöproblematiken. Martin Fehrms uppgift var där att understryka hur den pågående miljöförstörelsen drabbade människan på nästan alla områden. Särskilt skulle han lyfta fram hotens ekonomiska, hälsomässiga och säkerhetspolitiska dimensioner. Nyckelordet var "samordning" av såväl forskningsinsatser som politiska beslut. ${ }^{105}$

Av planerna på en gemensam skrift blev emellertid intet. Överst på en av sina PM-kopior har Birgitta Odén kortfattat skrivit "avvisat". ${ }^{06}$ Tänkbara förklaringar till detta finns i dokumentet "Min föredragning". Där reste hon själv frågan om det verkligen fordrades en gemensam skrift. "Eller har läget ändrats efter DN-debatten, Palmstiernas bok, Naturresurskommitténs betänkande och Naturvårdsverkets aktioner?"107 Frågorna vittnar om det jag visat på i detta kapitel. Mellan maj och november 1967 hade den svenska miljödebatten förändrats i grunden. Kunskaper och krisinsikter cirkulerade inte längre enbart i specifika 
kretsar, som på FOA, utan rörde sig med stor intensitet i offentligheten. Politiker och allmänhet hade vaknat upp.

Men vad kan vi egentligen veta om den sistnämnda kategorin? Går det att studera miljöfrågornas genombrott hösten 1967 utifrån den svenska allmänhetens perspektiv? Vilka spår finns kvar av dem som inte hörde till en skrivande samhällselit? Frågorna är inte enkla att besvara på ett tillfredsställande sätt. Men i Hans Palmstiernas rika personarkiv finns enstaka exempel. Det tidigaste jag har hittat härrör från en okänd göteborgare vid namn Sören Gunnarsson. I oktober 1967 tog han kontakt med Hans Palmstierna och inledde en brevväxling. I det följande ska jag titta närmare på denna för att därigenom belysa hur miljödebatten kunde gripa in i en lekmans liv. ${ }^{108}$

\section{Lekmannens röst}

Sören Gunnarsson inledde sitt första brev med att berätta att Hans Palmstiernas artiklar i Dagens Nyheter hade "betytt väldigt mycket för mej och stimulerat tankarna att kretsa kring de allvarliga problem Du skriver om". Gunnarsson lyfte fram att debatten om "föroreningar och utsugning av jorden" hade intensifierats under det senaste året. Han gav uttryck för en stigande olust och oro inför "den hänsynslöshet med vilken storindustrierna fördärvar framtida livsmöjligheter". Det kortsiktiga tänkandet var nästan lika "ödesdigert och utmanande" som utsugningen av tredje världen. Bekymrad vände han sig till Palmstierna för upplysningar och vägledning. Vad gjordes från ansvarigt håll? Hur agerade de som bar på insikten att människan var hotad? Vad kunde en lekman göra mer än att läsa vetenskapsmännens skrifter? Fanns det några påtryckningsgrupper eller upprop? Kunde man inte inrätta ett kansli som försåg pressen med information och debattartiklar? ${ }^{109}$

Palmstierna svarade Gunnarsson att problemens omfattning och människornas kortsiktiga vinningslystnad oroade honom djupt. Men samtidigt var han inte uppgiven: "Hade jag inte sett en strimma av hopp, så skulle jag inte ha skrivit den bok som kom ut i förra veckan; Plundring-Svält-Förgiftning. Den försöker attackera problemen, och där jag ser lösningar, ge några möjligheter.” Palmstierna manade Gun- 
narsson att stå upp och verka för förändring: "Den snabbaste vägen är antagligen via de politiska partierna. Jag försöker vad jag kan inom socialdemokratin, som ju är den mest ansvarsmedvetna i dessa frågor." Palmstierna lyfte också fram att det inom det naturvetenskapliga forskningsrådet hade bildats en ekologi-kommitté som var avsedd att fungera som en påtryckningsgrupp. Han avslutade med att instämma i Gunnarssons kritik av "egoistisk vinningslusta". Det var den som tvingade fram förstörelse av den gemensamma miljön. "Det borde inte finnas ägare", skrev Palmstierna, "i den meningen att man får förstöra sin egendom så att tredje man eller kommande generationer får lida. Det borde bara finnas förvaltare." 110

Sören Gunnarsson svarade med ett vykort. Han gladde sig åt att det var "en bok på gång" och hoppades den skulle bli en framgång. "Och att den måste fungera mer än andra 'väckarklockor' denna unika höst."111 Kort därefter skickade han över en tidningsartikel där några tekniker intervjuades. Han framhöll att artikeln inte i sig var någonting märkvärdigt, men att den tydligt visade på vilken skrämmande "aningslöshet" som teknikerna uppvisade på miljö- och energiområdet. ${ }^{112}$

Hans Palmstierna tackade Gunnarsson för "den naiva artikeln". Innehållet var dock, såvitt han förstod det, endast att man ville ha "en skickligare skött samhällsplanering och en skarpare kontroll". Palmstierna påpekade att det teknikerna sagt hade "silats genom journalistens klena intellekt" och underströk att dåliga journalister "älskar att sätta en larvig, gärna nedsättande kläm i slutet av en artikel". Detta särskilt när de inte har "kunnat följa med i samtalet". Möjligen hade "dessa teknikers diskussion varit riktigt vettig".

Artikeln föranledde Palmstierna att utveckla sina tankar kring kommunikationens villkor. Frågan om hur krisinsikterna skulle spridas till fler stod central för honom. Han tog avstånd från de som ansåg att information inte gick in hos människor om den inte var "enfaldig som en serie i söndagsbilagan". Detta synsätt var ett uttryck för högfärd, menade han, och dessutom direkt felaktigt: "Jag har märkt motsatsen. God information går hem.” Förutsättningen var att den inte framfördes på ett "enfaldigt och sårande sätt" utan på ett "omtänksamt och klokt sätt". ${ }^{113}$ 
Brevväxlingen mellan Hans Palmstierna och Sören Gunnarsson fortgick under hösten. Dessvärre är inte alla Gunnarssons brev bevarade. Utifrån Palmstiernas svar framgår det dock att ett par brev skrivna i november månad handlade om två vid tidpunkten aktuella miljövårdsfrågor på Västkusten. Den första punkten rörde Göteborgs stads avloppsvatten, vilket hotade Göta älv och de norra delarna av skärgården. Palmstierna argumenterade för att det borde inrättas ett nytt reningsoch avloppssystem som gjorde att "kloakernas material åter kommer till nytta för skogs- och jordbruk".

Den andra punkten rörde planerna på att anlägga en sulfatfabrik i Väröbacka, strax norr om Varberg. Det fanns vid tiden även planer på att anlägga ett atomkraftverk där. Här var Palmstierna dock inte lika kritisk mot den centrala planeringen. Han förklarade för Gunnarsson att det fanns stora fördelar med att industrier lokaliserades tätt: "Man kan då inte fördärva omgivningen utan att göra det omöjligt för folk att arbeta.” Detta satte press på att få fram renare processer. Dessutom gjorde koncentrationen det enklare för samhället att överblicka och kontrollera industrierna. ${ }^{114}$

Utöver de dagsaktuella politiska frågorna handlade brevväxlingen framför allt om hur miljökampen skulle organiseras och stärkas. Gunnarsson framhöll i sitt vykort att påtryckningsgrupper borde bildas, något Palmstierna instämde i. Den sistnämnde framhöll att vetenskapliga grupperingar höll på att formeras, men ansåg att det också skulle behövas en "lekmannakommitté". Som ett lyckat exempel på detta framhöll han Scientist and Citizen-gruppen i St. Louis vilken "från en ringa början blivit mycket inflytelserik". ${ }^{115}$

Palmstierna medgav att han stundtals "känt sig mycket ensam" och att han längtade "starkt efter en kampgrupp". Han framhöll dock att det sedan Plundring, svält, förgiftning publicerades hade visat sig "att det finns många vänner". På "sin lista" hade han både vetenskapsmän och administratörer. De var alla samhällsmedvetna och medvetet, eller omedvetet, röda. Särskilt framhöll Palmstierna poeten och författaren Svante Foerster som "ett bra och stridslystet namn". Han berättade också att han hade goda kontakter med den Stockholmsbaserade grup- 
pen Unga Filosofer: "Vi kan bilda en kampgrupp som liknar den och samtidigt den amerikanska St. Louis-gruppen."116

I brevets avslutning kommenterade han, med anledning av Gunnarssons framförda kritik, förlagets prissättning av Plundring, svält, förgiftning. Palmstierna betonade att han inte hade skrivit boken för att tjäna pengar och att det höga priset (22,50 SEK, cirka 200 SEK i dagens penningvärde) endast berodde på att förlaget inte trodde att den skulle sälja speciellt väl. Men den första upplagan av boken hade redan sålt slut: "Det kan inte betyda annat än att det finns åtskilliga människor som tänker som vi - i huvudsak." Palmstierna blickade optimistiskt framåt: "Låt oss skapa en folkrörelse. Tiden är inne för det."117

Brevväxlingen mellan Sören Gunnarsson och Hans Palmstierna är ett enskilt exempel. Av ett sådant går det inte att dra några långtgående slutsatser om hur människor i allmänhet berördes av och engagerades $i$ miljödebatten. Likväl indikerar brevväxlingen att kunskap cirkulerade i samhället. Det sociala avståndet mellan en lekman och en vetenskapsman var inte större än att en förtroendefull dialog kunde etableras. Gunnarsson tog egna initiativ, han skickade artiklar och ställde frågor. Palmstierna svarade utförligt. Brevväxlingen visar på en genuin vilja hos båda två att skapa förändring och kanalisera engagemang. Den pekar också på hur de stora överlevnadsperspektiven hakade i lokala frågor. Dessutom framgår det av breven att båda två upplevde att något nyligen hade hänt. Det hade skett ett samhälleligt kunskapsgenombrott.

Men ett konstaterande av detta slag väcker med självklarhet många frågor. Hur såg det ut tidigare? Vad var som det ledde fram till genombrottet? Och cirkulerade verkligen kunskap och expertis på helt andra sätt hösten 1967 än säg 1955 eller 1965? För att angripa den här typen av frågor krävs ett annat tillvägagångssätt än empiriskt närstudium av en avgränsad period. I nästa kapitel ska jag därför skifta optik och ta ett större grepp på efterkrigstidens första decennier. Jag kommer att ge en övergripande karaktärisering av centrala utvecklingslinjer, från sent 1940-tal till sommaren 1967, den period då kunskap om en global miljökris formerades. 